Published every April, August and December

JURNAL RISET AKUNTANSI \& KEUANGAN

ISSN:2541-061X (Online). ISSN:2338-1507(Print). http://ejournal.upi.edu/index.php/JRAK

\title{
Pengaruh Likuiditas, Solvabilitas, Profitabilitas, Rasio Pasar, dan Ukuran Perusahaan Terhadap Harga Saham (Studi Pada Perusahaan Subsektor Perkebunan Yang Terdaftar Di Bursa Efek Indonesia Tahun 2010-2014)
}

\author{
Nita Fitriani Arifin", Silviana Agustami² \\ ${ }^{1}$ Program Studi Akuntansi, FPEB, Universitas Pendidikan Indonesia, Bandung, Indonesia \\ ${ }^{2}$ Program Studi Akuntansi, FPEB, Universitas Pendidikan Indonesia, Bandung, Indonesia
}

\begin{abstract}
This study is aim to determine the effect of liquidity, solvability, profitability, market ratio, and firm size toward stock prize at plantation subsector companies which are listed in Indonesia Stock Exchange. This study use assosiative method with causal relationship. This study uses the variable liquidity, solvability, profitability, market ratio, and firm size as the independent variable and stock price as the dependent variable. This study use secondary data in annual financial statement. This study use the analysis multiple linear regression. The results of this study indicate that simultaneously liquidity, solvability, profitability, market ratio, and firm size give a significant effect toward stock price. Partially, liquidity and solvability have a negative effect toward stock price, while profitability, market ratio, and firm size have a positive effect toward stock price.

Keywords: Firm Size, Liquidity; Market Ratio; Profitability; Solvability; Stock Price.
\end{abstract}

Abstrak. Penelitian ini bertujuan untuk mengetahui pengaruh likuiditas, solvabilitas, profitabilitas, rasio pasar, dan ukuran perusahaan terhadap harga saham pada perusahaan subsektor perkebunan yang tercatat di Bursa Efek Indonesia. Penelitian ini menggunakan metode assosiative dengan hubungan kausal. Penelitian ini menggunakan variabel likuiditas, solvabilitas, profitabilitas, rasio pasar, dan ukuran perusahaan sebagai variabel bebas dan harga saham sebagai variabel terikat. Penelitian ini menggunakan data sekunder dalam laporan keuangan tahunan. Penelitian ini menggunakan analisis regresi linier berganda. Hasil penelitian ini menunjukkan bahwa secara bersamaan likuiditas, solvabilitas, profitabilitas, rasio pasar, dan ukuran perusahaan memberikan pengaruh yang signifikan terhadap harga saham. Sebagian, likuiditas dan solvabilitas berpengaruh negatif terhadap harga saham, sedangkan profitabilitas, rasio pasar, dan ukuran perusahaan berpengaruh positif terhadap harga saham.

Kata Kunci: Harga Saham; Likuiditas; Profitabilitas; Rasio Pasar; Solvabilitas; Ukuran Perusahaan.

Corresponding author. Email: ${ }^{1}$ nitafitrianiarifin@gmail.com, ${ }^{2}$ silviana.agustami@ upi.edu

How to cite this article. Nita Fitriani Arifin, S. A. (2016). Pengaruh Likuiditas, Solvabilitas, Profitabilitas, Rasio Pasar, Dan Ukuran Perusahaan Terhadap Harga Saham (Studi Pada Perusahaan Subsektor Perkebunan Yang Terdaftar Di Bursa Efek Indonesia Tahun 2010-2014). Jurnal Riset Akuntansi Dan Keuangan Program Studi Akuntansi Fakultas Pendidikan Ekonomi Dan Bisnis Universitas Pendidikan Indonesia, 4(3), 1189-1210. Retrieved from http://ejournal.upi.edu/index.php/JRAK/article/view/4673

History of article. Received: September 2016, Revision: November 2016, Published: December 2016 Online ISSN: 2541-061X.Print ISSN: 2338-1507. DOI: 10.17509/jrak.v4i3.4673

Copyright@2016. Published by Jurnal Riset Akuntansi dan Keuangan. Program Studi Akuntansi. FPEB. UPI 


\section{PENDAHULUAN}

Di Bursa Efek Indonesia, perusahaanperusahaan yang terdaftar dikelompokkan ke dalam sembilan sektor. Salah satu sektor yang berperan penting di pasar modal Indonesia adalah sektor pertanian yang terdiri dari empat subsektor, yaitu subsektor tanaman pangan, subsektor perkebunan, subsektor perikanan, dan subsektor peternakan. Diantara keempat subsektor tersebut, subsektor perkebunan merupakan kelompok yang berkembang baik dan mampu memberikan kontribusi yang cukup besar pada pembangunan ekonomi Indonesia.

Indonesia merupakan negara produsen minyak mentah sawit (crude palm oil/CPO) terbesar di dunia, dengan produksi pada tahun 2012 mencapai 29,5 juta atau 54\% dari total produksi CPO di dunia (Majalah Media Industri, 2013:23). Minyak kelapa sawit (crude palm oil/CPO), karet, biji kakao, dan kopi merupakan komoditas perkebunan penyumbang ekspor tertinggi Indonesia. Meski sedikit menurun akibat krisis Eropa dan AS, empat komoditas ini masih menjadi andalan ekspor pada tahun 2012. Pada periode 2008-2009, harga beberapa komoditas perkebunan unggulan Indonesia turun secara drastis, CPO $-26,3 \%$, karet $-32,4 \%$, kopi $13,4 \%$, dan hanya harga kakao yang naik $11,7 \%$. Untuk beberapa komoditas, seperti CPO dan kopi, penurunan harga yang drastis tersebut justru berlawanan dengan permintaan atau konsumsi yang tetap naik atau stabil volumenya pada waktu itu (www.investor.co.id). Namun, sejak tahun 2010, kinerja ekspor komoditas perkebunan semakin membaik. Kontribusi PDB subsektor perkebunan terhadap sektor pertanian atas dasar harga berlaku meningkat $8,14 \%$ dari $19,9 \%$ pada tahun 2011 menjadi $21,52 \%$ pada tahun 2012, untuk PDB atas dasar harga konstan 2000 meningkat $30,98 \%$ dari $18,6 \%$ pada tahun 2011 menjadi $24,36 \%$ di tahun 2012 (ekonomi.inilah.com).

Rata-rata jumlah asset subsektor perkebunan mengalami peningkatan. Tahun 2010, rata-rata asset subsektor perkebunan berjumlah Rp7.872 miliar, tahun 2011 berkembang menjadi Rp9.195,2 miliar, tahun
2012 berjumlah Rp9.521,91 miliar, tahun 2013 berjumlah Rp10.379,5 miliar, dan tahun 2014 menjadi Rp12.421,6 miliar. Perkembangan asset tersebut diikuti dengan jumlah utang, modal, penjualan, dan laba bersih yang mengalami peningkatan. Rata-rata utang subsektor perkebunan tahun 2010 berjumlah Rp3.644,1 miliar, tahun 2011 meningkat menjadi Rp3.794,7 miliar, tahun 2012 menjadi Rp4.210 miliar, tahun 2013 bertambah menjadi Rp5.348 miliar, dan tahun 2014 menjadi Rp6.517,7 miliar. Pada tahun 2010 rata-rata jumlah modal subsektor perkebunan sebesar Rp3.965,7 miliar dan rata-rata penjualannya mencapai Rp5.203,3 miliar. Tahun 2011 jumlah modalnya menjadi Rp5.400,5 miliar dan penjualannya meningkat menjadi Rp7.300,9 miliar. Sedangkan tahun 2012 modal dan penjualannya mengalami sedikit penurunan menjadi Rp5.311,5 miliar dan Rp6.277,6 miliar. Penurunan modal dan penjualan kembali terjadi pada tahun 2013 menjadi Rp5.031,6 miliar dan Rp5.936,2 miliar. Di tahun 2014 jumlah modal dan penjualan mengalami peningkatan menjadi Rp5.903,7 miliar dan Rp7.736,4 miliar. Jumlah rata-rata laba bersih perusahaan subsektor perkebunan pada tahun 2010 berjumlah Rp727,2 miliar, tahun 2011 berjumlah Rp1.170,1 miliar, tahun 2012 dan 2013 mengalami penurunan seiring dengan penurunan jumlah modal dan penjualan menjadi Rp645,7 miliar dan Rp125,8 miliar, tahun 2014 jumlah rata-rata laba bersih mengalami peningkatan menjadi Rp663,9 miliar. Fluktuasi data yang terjadi pada tahun beberapa tahun terakhir tidak berpengaruh terhadap permintaan ekspor komoditas subsektor perkebunan.

Perkembangan positif perusahaan subsektor perkebunan tersebut tidak terlihat dalam pergerakan harga saham di pasar modal. Meskipun mengalami perkembangan yang baik, harga saham perusahaan subsektor perkebunan cenderung menurun dari tahun 2010 hingga 2014. Subsektor yang mengalami penurunan adalah subsektor tanaman pangan, perkebunan, dan peternakan. Sedangkan subsektor perikanan harga sahamnya mengalami peningkatan. Dari ketiga subsektor 
yang mengalami penurunan harga saham, subsektor perkebunan mengalami penurunan yang paling tinggi jika dibandingkan dengan subsektor tanaman pangan dan peternakan.

Penurunan harga saham yang terjadi membuat investor memberikan penilaian yang buruk terhadap kinerja perusahaan dalam mengelola usahanya. Dengan demikian, jumlah investasi yang akan ditanamkan oleh investor kepada perusahaan pun akan ikut menurun, karena harga saham sering dianggap sebagai salah satu faktor yang mencerminkan kinerja perusahaan. Jika harga saham mengalami penurunan, maka kinerja perusahaan dinilai buruk dan permintaan akan pembelian saham pun akan menurun. Sebaliknya, jika harga saham meningkat, maka kinerja perusahaan dinilai baik dan permintaan pembelian saham akan meningkat.

Harga saham dipengaruhi oleh rasiorasio keuangan seperti likuiditas, solvabilitas, profitabilitas, rasio pasar, rasio aktivitas, dan rasio lainnya. Dalam penelitian ini, rasio yang digunakan adalah likuiditas, solvabilitas, profitabilitas, dan rasio pasar. Selain itu ditambah dengan ukuran perusahaan.

Likuiditas merupakan kemampuan perusahaan dalam memenuhi kewajiban jangka pendeknya. Perusahaan yang likuid akan dengan mudah memenuhi kewajiban tersebut. Jika perusahaan likuid maka kinerja perusahaan dinilai baik oleh investor. Seiring dengan naiknya penilaian kinerja perusahaan di mata investor maka harga saham pun akan ikut naik. Jenis rasio likuiditas yang digunakan dalam penelitian ini adalah current ratio karena rasio ini dianggap dapat membandingkan penilaian likuiditas antara satu perusahaan dengan perusahaan lain. Current ratio dihitung dengan membandingkan jumlah asset lancar dengan utang lancar. Jumlah utang perusahaan subsektor perkebunan tahun 2010 rata-rata berjumlah Rp3.644,1 miliar, tahun 2011 meningkat menjadi Rp3.794,7 miliar, tahun 2012 menjadi Rp4.210 miliar, tahun 2013 menjadi Rp5.348 miliar, dan tahun 2014 menjadi Rp6.517,7 miliar. Peningkatan jumlah utang tersebut diiringi dengan peningkatan jumlah asset, tahun 2010 rata- rata asset subsektor perkebunan berjumlah Rp7.872 miliar, tahun 2011 berkembang menjadi Rp9.195,2 miliar, tahun 2012 menjadi Rp9.521,91 miliar, tahun 2013 menjadi Rp10.379,5 miliar, dan tahun 2014 menjadi Rp12.421,6 miliar. Dengan demikian, seharusnya perusahaan subsektor perkebunan dapat memenuhi kewajiban jangka pendeknya sehingga perusahaan dikatakan likuid agar kinerja perusahaan dinilai baik dan harga saham dapat meningkat.

Solvabilitas adalah rasio yang digunakan untuk mengetahui kemampuan perusahaan dalam membayar utang jangka panjang. Rasio ini mengukur seberapa besar perusahaan dibiayai oleh utang. Rasio solvabilitas yang digunakan dalam penelitian ini adalah debt to equity ratio, yaitu rasio yang menggambarkan perbandingan antara total utang dengan total modal perusahaan yang digunakan sebagai modal usaha. Jika debt to equity ratio suatu perusahaan tinggi maka para investor akan menghindari saham tersebut, akibatnya permintaan akan saham tersebut menurun dan mengakibatkan harga saham turun (Hijriah, 2007). Meskipun jumlah utang perusahaan subsektor perkebunan terus meningkat yaitu rata-rata utang subsektor perkebunan tahun 2010 berjumlah Rp3.644,1 miliar, tahun 2011 meningkat menjadi Rp3.794,7 miliar, tahun 2012 menjadi Rp4.210 miliar, tahun 2013 bertambah menjadi Rp5.348 miliar, dan tahun 2014 menjadi Rp6.517,7 miliar seharusnya perusahaan tetap dapat memenuhi kewajiban jangka panjangnya dengan modal yang dimiliki.

Profitabilitas merupakan rasio yang menunjukkan kemampuan perusahaan untuk menghasilkan laba (Kodrat dan Indonanjaya, 2010:239). Profitabilitas sering mendapat perhatian utama dari para investor. Dalam penelitian ini, return on equity digunakan untuk mengukur profitabilitas, karena rasio ini dapat mengukur kemampuan perusahaan dalam menghasilkan keuntungan atas modal yang investor tanamkan. Bodie (2003:465) menyatakan tingkat return on equity yang tinggi dapat diartikan bahwa perusahaan akan memberikan peluang tingkat pengembalian atau pendapatan yang cukup besar bagi para 
investor sehingga memberikan peluang akan meningkatnya harga saham perusahaan tersebut. Dengan data yang menyatakan bahwa laba bersih perusahaan subsektor perkebunan tahun 2010 berjumlah Rp727,2 miliar, tahun 2011 berjumlah Rp1.170,1 miliar, tahun 2012 berjumlah Rp645,7 miliar, tahun 2013 berjumlah Rp125,8 miliar, tahun 2014 menjadi Rp663,9 miliar, serta modal tahun 2010 sebesar Rp3.965,7 miliar, tahun 2011 menjadi Rp5.400,5 miliar, tahun 2012 modal menjadi Rp5.311,5 miliar, tahun 2013 Rp5.031,6, dan tahun 2014 Rp5903,7 miliar seharusnya return on equity perusahaan tinggi sehingga keuntungan yang dihasilkan semakin besar dan harga saham naik.

Rasio pasar adalah rasio yang menunjukkan informasi perusahaan yang dinilai per saham. Dalam penelitian ini rasio pasar yang digunakan adalah earning per share, yaitu rasio untuk mengukur keuntungan yang diberikan perusahaan kepada investor atas setiap lembar saham yang dimiliki. Earning per share yang tinggi akan membuat permintaan atas saham perusahaan meningkat dimana tingginya permintaan saham ini akan menyebabkan harga saham perusahaan bergerak naik (Ang, 1997). Dengan data yang menyatakan bahwa laba bersih perusahaan subsektor perkebunan pada tahun 2010 hingga 2014 mengalami peningkatan seharusnya mendorong harga saham untuk bergerak naik.

Faktor lain yang mempengaruhi harga saham adalah ukuran perusahaan, yaitu ukuran yang mengklasifikasikan besar kecilnya perusahaan melalui asset yang dimiliki, penjualan, atau kapitalisasi pasar. Semakin besar ukuran perusahaan yang dapat dilihat dari total aktiva maka harga saham perusahaan akan semakin tinggi, sedangkan jika ukuran perusahaan semakin kecil maka harga saham perusahaan akan semakin rendah (Edward et al dalam Sofilda dan Subaedi, 2006). Jika dilihat dari total aktiva, seharusnya harga saham perusahaan subsektor perkebunan mengalami peningkatan karena jumlah rata-rata pertumbuhan asset yang dimiliki terus bertambah pada tahun 2010 hingga 2014.
Berdasarkan latar belakang tersebut, maka peneliti tertarik untuk mengambil judul penelitian "Pengaruh Likuiditas, Solvabilitas, Profitabilitas, Rasio Pasar, dan Ukuran Perusahaan Terhadap Harga Saham (Studi Pada Perusahaan Subsektor Perkebunan yang Terdaftar Di Bursa Efek Indonesia Tahun 2010-2014)".

Berdasarkan uraian latar belakang tersebut, perumusan masalah dalam penelitian ini adalah sebagai berikut: Bagaimana pengaruh likuiditas, solvabilitas, profitabilitas, rasio pasar, dan ukuran perusahaan secara bersama-sama terhadap harga saham perusahaan subsektor perkebunan yang terdaftar di BEI tahun 2010-2014; Bagaimana pengaruh likuiditas terhadap harga saham perusahaan subsektor perkebunan yang terdaftar di BEI tahun 2010-2014; Bagaimana pengaruh solvabilitas terhadap harga saham perusahaan subsektor perkebunan yang terdaftar di BEI tahun 2010-2014; Bagaimana pengaruh profitabilitas terhadap harga saham perusahaan subsektor perkebunan yang terdaftar di BEI tahun 2010-2014; Bagaimana pengaruh rasio pasar terhadap harga saham perusahaan subsektor perkebunan yang terdaftar di BEI tahun 2010-2014; Bagaimana pengaruh ukuran perusahaan terhadap harga saham perusahaan subsektor perkebunan yang terdaftar di BEI tahun 2010-2014.

\section{KAJIAN LITERATUR}

Perkembangan ekonomi di zaman globalisasi saat ini tumbuh dengan pesat sehingga membuat perusahaan membutuhkan dana yang cukup besar agar mampu bersaing dan menjalankan kegiatan usahanya. Untuk memperoleh dana tersebut, perusahaan mencarinya melalui pasar modal yang dijadikan sebagai sumber dana alternatif bagi perusahaan. Pasar modal adalah pasar tempat bertemunya penjual dan pembeli instrumen keuangan jangka panjang seperti saham, obligasi, reksa dana, waran, dan lain-lain. Di pasar modal, perusahaan dapat menjual instrumen keuangan yang dimilikinya kepada investor untuk mendapatkan tambahan dana, sedangkan investor dapat menyalurkan dana yang dimilikinya untuk membeli instrumen 
keuangan tersebut dengan tujuan ingin memperoleh keuntungan. Oleh karena itu, pasar modal memiliki peran penting dalam perekonomian suatu negara dan sering dijadikan salah satu indikator untuk mengukur maju tidaknya perekonomian suatu negara, termasuk Indonesia.Kemajuan suatu pasar modal dapat dipengaruhi oleh efisien atau tidaknya suatu pasar. Pasar modal yang efisien adalah pasar modal yang menyediakan informasi secara cepat dan mudah kepada investor dimana informasi tersebut tercermin dalam harga-harga sekuritas yang diperjualbelikan di pasar modal, sehingga investor tidak perlu susah payah mencari informasi terkait sekuritas tersebut. Dengan adanya efisiensi pasar modal, kepercayaan investor akan lebih meningkat karena adanya transparansi dalam penyampaian informasi, terutama jika informasi tersebut lengkap, tepat, dan akurat.

Investor yang akan berinvestasi di pasar modal memerlukan informasi, terutama yang berkaitan dengan kinerja keuangan perusahaan, karena informasi merupakan kebutuhan yang mendasar bagi para investor. Dengan mengetahui keadaaan keuangan perusahaan, investor dapat memprediksi bagaimana prospek perusahaan di masa mendatang, bagaimana harga dan prospek sekuritas yang akan dipilih, seberapa besar keuntungan yang dapat diberikan perusahaan kepada investor atas modal yang ditanamkannya, serta informasi lain yang bermanfaat.

Di antara berbagai instrumen keuangan yang diperjualbelikan di pasar modal, saham merupakan instrumen keuangan yang paling banyak diminati oleh investor. Saham merupakan tanda kepemilikan modal seseorang atau badan usaha dalam suatu perusahaan. Para investor tertarik untuk membeli saham karena saham menjanjikan keuntungan yang besar kepada pemiliknya, baik berupa dividen maupun capital gains. Namun dibalik keuntungan yang dijanjikan, saham juga termasuk instrumen keuangan yang mengandung risiko tinggi. Hal itu dikarenakan sifat saham yang sangat peka terhadap perubahan-perubahan yang terjadi.
Oleh karena itu, ketika akan berinvestasi saham para investor perlu melakukan analisis terhadap faktor-faktor yang dapat mempengaruhi saham dan kondisi perusahaan agar mereka dapat meminimalisasi risiko dan dapat memprediksi keuntungan yang akan diperoleh.

Analisis terhadap kondisi keuangan perusahaan merupakan langkah awal yang sering dilakukan oleh investor ketika akan memutuskan berinvestasi saham. Keputusan investasi sangat penting bagi perusahaan, karena keputusan itu dapat mempengaruhi jumlah modal dan kinerja keuangan perusahaan. Dalam menganalisis kondisi perusahaan, investor akan menaruh perhatian utama terhadap keuntungan yang akan mereka peroleh.

Selain keuntungan, hal lain yang menjadi perhatian investor adalah harga saham. Harga saham memiliki arti penting, karena harga saham dapat mempengaruhi minat dan kepercayaan investor untuk membeli saham sebagai bentuk investasi di suatu perusahaan. Menurut Jogiyanto (2008:8) harga saham adalah harga yang terjadi di pasar bursa pada saat tertentu yang ditentukan oleh pelaku pasar dan ditentukan oleh permintaan dan penawaran saham yang bersangkutan di pasar modal, harga saham biasanya ditunjukkan pada harga penutupannya (closing price). Harga saham dapat dijadikan salah satu indikator untuk menilai keberhasilan perusahaan dalam mengelola dana yang dimiliki guna menjalankan kegiatan usahanya. Jika harga saham perusahaan bergerak naik, maka investor menganggap perusahaan berhasil mengelola kegiatan usahanya.

Harga saham selalu mengalami fluktuasi. Fluktuasi tersebut dipengaruhi oleh adanya interaksi antara permintaan dan penawaran saham di pasar modal oleh investor. Hal tersebut diperkuat oleh Rusdin (2008:66) yang menyatakan bahwa harga saham ditentukan menurut hukum permintaan dan penawaran atau hukum kekuatan tawar menawar, makin banyak orang yang ingin membeli maka harga saham tersebut cenderung naik, sebaliknya makin banyak 
orang yang ingin menjual saham maka harga saham tersebut akan bergerak turun. Pergerakan saham ini menjadi daya tarik bagi investor, karena dapat memberikan kesempatan investor untuk memperoleh keuntungan selain dividen, yaitu berupa capital gains. Namun, investor tetap harus waspada terhadap pergerakan harga saham. Dengan terjadinya pergerakan harga saham investor harus menyadari bahwa tidak selamanya investasi saham akan memberikan keuntungan, adakalanya investor akan mengalami kerugian.

Untuk menganalisis pergerakan harga saham, cara yang dapat dilakukan investor adalah dengan melakukan analisis teknikal dan analisis fundamental. Analisis teknikal lebih fokus memperhatikan keadaan pasar dan mempelajari grafik harga saham Biasanya analisis teknikal digunakan untuk menganalisis harga saham dalam jangka waktu pendek. Sedangkan analisis fundamental berkaitan dengan kondisi keuangan perusahaan, faktor-faktor fundamental inilah yang mempengaruhi harga saham dalam jangka panjang. Seperti yang dikatakan oleh Wijayanti (2010) bahwa harga saham berubah (berfluktuasi) sesuai dengan kekuatan permintaan (demand) dan penawaran (supply), salah satu faktor yang mempengaruhi pembelian saham (permintaan) didasarkan pada pertimbangan fundamental yaitu kinerja keuangan perusahaan, dengan kinerja keuangan yang baik perusahaan tersebut mampu menghasilkan keuntungan yang tinggi dan sekaligus dapat menyisihkan bagian keuntungan itu sebagai dividen yang tinggi pula, sehingga hal tersebut akan mempengaruhi permintaan akan saham.

Berdasarkan penjelasan di atas, dapat disimpulkan bahwa permintaan akan saham dan pergerakan harga saham dipengaruhi oleh faktor fundamental, yaitu faktor yang berkaitan dengan kinerja perusahaan, khususnya kinerja keuangan. Jika kinerja keuangan perusahaan baik, maka permintaan dari investor untuk membeli saham akan naik, dengan begitu harga saham pun ikut naik.

Analisis fundamental yang sering digunakan untuk menilai harga saham adalah dengan menganalisa kinerja keuangan perusahaan melalui analisis rasio yang datanya berasal dari laporan keuangan. Rasio keuangan ini memang dikenal mampu menganalisis kinerja suatu perusahaan dengan cepat, karena cara ini berupa proses penyederhanaan informasi dengan membandingkan angka yang ada di pos-pos laporan keuangan. Dengan angka-angka didalamnya, kita dapat menganalisa keadaan perusahaan. Jika kondisi keuangan perusahaan sehat, maka memiliki peluang besar untuk mencetak laba di masa-masa mendatang sehingga bisa diharapkan untuk membagi dividen atau membayar bunga obligasi dan harga saham atau obligasi juga bisa meningkat (Widoatmodjo, 2009:66).

Dalam penelitian ini, rasio keuangan digunakan untuk mengetahui bagaimana pengaruhnya terhadap harga saham. Hal itu disebabkan rasio keuangan dapat mengukur kinerja keuangan perusahaan menggunakan data-data yang berasal dari laporan keuangan. Jika kondisi keuangan perusahaan baik, maka investor akan menilai bahwa perusahaan berhasil menjalankan usahanya. Dengan demikian permintaan untuk membeli saham perusahaan akan meningkat, sehingga harga saham pun ikut naik.

Seperti yang dijelaskan oleh Zuliarni (2012) bahwa salah satu faktor yang mempengaruhi harga saham adalah kondisi perusahaan, dalam hal ini diartikan sebagai kinerja keuangan perusahaan, kinerja perusahaan merupakan suatu hal yang sangat penting, karena kinerja perusahaan berpengaruh dan dapat digunakan sebagai alat untuk mengetahui apakah perusahaan mengalami perkembangan atau sebaliknya, ukuran kinerja perusahaan yang paling lama dan paling banyak digunakan adalah kinerja keuangan yang diukur dari laporan keuangan perusahaan, analisis terhadap laporan keuangan dapat dilakukan dengan cara perhitungan rasio keuangan, jenis rasio keuangan yang sering digunakan dalam menilai kinerja keuangan perusahaan adalah rasio likuiditas, rasio aktivitas, rasio solvabilitas, rasio profitabilitas, dan rasio pasar. 
Berdasarkan penjelasan di atas, penelitian ini menggunakan rasio likuiditas, solvabilitas, profitabilitas, rasio pasar, dan ukuran perusahaan untuk menilai harga saham. Berikut penjelasan pengaruh rasiorasio tersebut terhadap harga saham.

Likuiditas merupakan suatu indikator mengenai kemampuan perusahaan untuk membayar semua kemampuan finansial jangka pendek pada saat jatuh tempo dengan menggunakan aktiva lancar yang tersedia (Syamsuddin, 2009:41). Tingkat likuiditas suatu perusahaan dapat mempengaruhi investor dalam mengambil keputusan untuk menanamkan modalnya, investor lebih percaya untuk menanamkan modal pada perusahaan yang likuid dibandingkan yang kurang atau tidak likuid. Suatu perusahaan dikatakan likuid apabila perusahaan tersebut memiliki kemampuan untuk membayar utang jangka pendeknya dengan baik. Rasio likuiditas yang digunakan dalam penelitian ini adalah current ratio. Current ratio dipilih karena rasio ini dapat digunakan sebagai pembanding dengan likuiditas perusahaan lain. Kaitannya dengan harga saham adalah jika likuiditas meningkat maka harga saham cenderung naik karena investor menganggap bahwa perusahaan dapat dikatakan likuid.

Solvabilitas merupakan rasio yang menggambarkan kemampuan perusahaan dalam membayar kewajiban jangka panjangnya atau kewajiban-kewajibannya apabila perusahaan dilikuidasi (Harahap, 1999:303). Rasio solvabilitas yang digunakan dalam penelitian ini adalah debt to equity ratio, yaitu rasio yang membandingkan total utang milik perusahaan dengan modal yang dimiliki. Ang (1997:18.34-18.35) menyatakan debt to equity ratio yang tinggi mempunyai dampak yang buruk terhadap kinerja perusahaan, karena tingkat utang semakin tinggi, yang berarti beban bunga akan semakin besar sehingga dapat mengurangi keuntungan, dengan begitu harga saham cenderung mengalami penurunan, sebaliknya, tingkat debt to equity ratio yang kecil menunjukkan kinerja yang semakin baik, karena menyebabkan tingkat pengembalian yang semakin tinggi, dengan kondisi seperti ini harga saham akan naik.

Profitabilitas merupakan kemampuan perusahaan untuk menghasilkan laba dalam satu periode tertentu baik melalui aktiva maupun melalui modal yang dimiliki. Perusahaan dinilai berhasil jika memiliki profitabilitas yang tinggi. Dengan begitu, investor semakin tertarik untuk berinvestasi karena beranggapan bahwa mereka akan mendapat keuntungan yang besar. Selanjutnya, harga saham akan terdorong naik karena adanya permintaan pembelian saham dari investor. Rasio profitabilitas yang digunakan dalam penelitian ini adalah return on equity, yaitu rasio yang mengukur keuntungan dengan membandingkan laba bersih dengan total modal. Tingkat ROE memiliki hubungan yang positif dengan harga saham, sehingga semakin besar ROE semakin besar pula harga pasar karena besarnya ROE memberikan indikasi bahwa pengembalian yang akan diterima investor akan tinggi sehingga investor akan tertarik untuk membeli saham tersebut dan hal ini menyebabkan harga pasar saham cenderung naik (Harahap, 2007:156).

Rasio pasar adalah rasio yang berisi informasi penting perusahaan yang dinilai per saham. Dalam penelitian ini, rasio pasar yang digunakan adalah earning per share. Earning per share merupakan rasio yang dapat mengukur kemampuan perusahaan untuk menghasilkan keuntungan dalam setiap lembar sahamnya. Rasio ini dihitung dengan membandingkan jumlah laba bersih dengan jumlah saham yang beredar. Investor tertarik untuk berinvestasi di suatu perusahaan apabila jumlah earning per share perusahaan besar, sehingga harga saham pun akan ikut meningkat. Earning per share yang tinggi akan membuat permintaan atas saham perusahaan meningkat dimana tingginya permintaan saham ini akan menyebabkan harga saham perusahaan bergerak naik (Ang, 1997).

Ukuran perusahaan merupakan suatu skala yang dapat mengklasifikasikan besar kecilnya suatu perusahaan. Ukuran perusahaan dapat diukur dengan total aktiva, 
penjualan, dan kapitalisasi pasar. Dalam penelitian ini, ukuran perusahaan diukur dengan total aktiva dengan menggunakan perhitungan logaritma natural. Perusahaan dengan jumlah aktiva yang tinggi sering dinilai sebagai perusahaan dengan prospek yang baik dan dapat memberikan keuntungan kepada pemegang saham, sehingga saham tersebut apat bertahan di pasar modal dan harganya akan naik jika banyak diminati investor. Semakin besar ukuran perusahaan yang dapat dilihat dari total aktiva maka harga saham perusahaan akan semakin tinggi, sedangkan jika ukuran perusahaan semakin kecil maka harga saham perusahaan akan semakin rendah (Edward et al dalam Sofilda dan Subaedi, 2006).

Berdasarkan rumusan masalah, penjelasan dan teori yang ada, hipotesis yang diajukan dalam penelitian ini adalah sebagai berikut.

H1 : Likuiditas, solvabilitas, profitabilitas, rasio pasar, ukuran perusahaan

berpengaruh secara simultan terhadap harga saham.

H2 : Likuiditas berpengaruh positif terhadap harga saham.

H3 : Solvabilitas berpengaruh negatif terhadap harga saham.

H4 : Profitabilitas berpengaruh positif terhadap harga saham.

H5 : Rasio pasar berpengaruh positif terhadap harga saham.

H6 : Ukuran perusahaan berpengaruh positif terhadap harga saham.

\section{METODOLOGI PENELITIAN}

Penelitian ini dimaksudkan untuk mengetahui ada atau tidaknya pengaruh variabel independen terhadap variabel dependen. Desain penelitian yang digunakan dalam penelitian ini adalah desain penelitian asosiatif dengan bentuk hubungan kausal. Hal ini dikarenakan penelitian ini menggunakan rumusan masalah asosiatif dengan hubungan kausal untuk mengetahui pengaruh dari likuiditas, solvabilitas, profitabilitas, rasio pasar, dan ukuran perusahaan terhadap harga saham pada perusahaan subsektor perkebunan yang terdaftar di Bursa Efek Indonesia tahun
2010-2014. Penelitian dengan desain kausal adalah penelitian yang berguna untuk mengukur hubungan-hubungan antarvariabel penelitian atau berguna untuk menganalisis bagaimana suatu variabel mempengaruhi variabel lain (Umar, 2008:8). Jenis data yang digunakan dalam penelitian ini adalah data dengan sumber sekunder yang diperoleh dari situs Bursa Efek Indonesia (www.idx.co.id) dan website masing-masing perusahaan.

Populasi dalam penelitian ini adalah seluruh perusahaan subsektor perkebunan yang terdaftar di BEI tahun 2010-2014. Kemudian dilakukan pengambilan sampel dengan teknik purposive sampling sehingga diperoleh enam perusahaan subsektor perkebunan sebagai sampel yang digunakan dalam penelitian ini.

Dalam penelitian ini, yang menjadi variabel dependen adalah harga saham perusahaan. Dan yang menjadi variabel independen adalah yaitu likuiditas, solvabilitas, profitabilitas, rasio pasar, dan ukuran perusahaan.

\section{Harga Saham}

Menurut Jogiyanto (2008:8) harga saham diartikan sebagai harga yang terjadi di pasar bursa pada saat tertentu ditentukan oleh pelaku pasar dan ditentukan oleh permintaan dan penawaran saham yang bersangkutan di pasar modal, harga saham dihitung dari harga penutupan (closing price) pada akhir tahun transaksi.

\section{Likuiditas}

Alat ukur likuiditas yang digunakan dalam penelitian ini adalah current ratio, yang ditentukan dengan jalan membandingkan antara current assets dengan current liabilities.

$$
\begin{aligned}
& \text { Current Ratio } \\
& =\frac{\text { Current Assets }}{\text { Current Liabilities }} \times 100 \%
\end{aligned}
$$

(Syamsuddin, 2009:43)

\section{Solvabilitas}

Dalam menghitung solvabilitas, penelitian ini menggunakan debt to equity ratio yang diukur dengan membagi total kewajiban dengan ekuitas pemegang saham. 


\section{Debt to Equity Ratio = $\frac{\text { Total Debt }}{\text { Total Equity }} \times 100 \%$ \\ (Harahap, 1999:303)}

\section{Profitabilitas}

Dalam penelitian ini, profitabilitas diukur menggunakan return on equity karena return on equity menggambarkan kemampuan perusahaan dalam menghasilkan laba yang bisa diperoleh pemegang saham dengan menggunakan modal sendiri. Rasio ini menunjukkan berapa persen diperoleh laba bersih bila diukur dari modal pemilik, semakin besar semakin bagus (Harahap, 2011:305). Return on equity dihitung dengan rumus berikut.

$$
\begin{aligned}
R O E= & \frac{\text { Net Earning }}{\text { Total Equity }} \times 100 \% \\
& \text { (Rivai dkk, 2013:163) }
\end{aligned}
$$

\section{Rasio Pasar}

Rasio pasar yang digunakan dalam penelitian ini adalah earning per share (EPS). Earning per share merupakan indikator untuk mengukur seberapa besar tiap lembar saham dapat menghasilkan keuntungan bagi pemiliknya. EPS dirumuskan sebagai berikut.

$$
\begin{gathered}
\text { Earning Per Share } \\
=\frac{\text { Net Earning }}{\text { Number of Share Outstanding }} \\
\text { (Rivai dkk, 2013:163) }
\end{gathered}
$$

\section{Ukuran Perusahaan}

Variabel ukuran perusahaan diukur dengan menggunakan logaritma natural dari total aktiva, logaritma natural dipilih untuk meratakan data atau menghindari rentang data yang terlalu jauh, selain itu total aktiva dianggap memiliki jumlah yang lebih stabil dibandingkan total penjualan maupun kapitalisasi pasar (Jogiyanto, 2000:254). Dalam penelitian ini, ukuran perusahaan dihitung seperti berikut.

\section{Ukuran Perusahaan $=\ln$ Total Aktiva (Jogiyanto, 2000:254)}

Analisis data menggunakan metode statistik deskriptif yang bertujuan untuk mengetahui nilai rata-rata, maksimum, minimum, dan standar deviasi dari variabel yang diteliti. Sebelum melakukan uji hipotesis, terlebih dahulu dilakukan uji asumsi klasik. Uji asumsi klasik yang dilakukan adalah uji normalitas, multikolinieritas, heteroskedastisitas, dan autokorelasi. Penelitian ini menggunakan regresi linier berganda yang digunakan untuk menguji pengaruh likuiditas, solvabilitas, profitabilitas, rasio pasar, dan ukuran perusahaan terhadap harga saham. Model regresi linier berganda yang digunakan untuk menguji hipotesis sebagai berikut.

$$
\begin{gathered}
Y=\alpha+\beta_{1} X_{1}+\beta_{2} X_{2}+\beta_{3} X_{3}+\beta_{4} X_{4}+ \\
\beta_{5} X_{5}+e
\end{gathered}
$$

Keterangan:

$Y=$ Harga Saham

$\alpha=$ Konstanta

$\beta_{1}, \beta_{2,} \beta_{3,} \beta_{4}, \beta_{5}=$ koefisien regresi

$X_{1}=$ Likuiditas

$X_{2}=$ Solvabilitas

$X_{3}=$ Profitabilitas

$X_{4}=$ Rasio Pasar

$X_{5}=$ Ukuran Perusahaan

$e=$ Kesalahan residual

Untuk pengujian hipotesis, penelitian ini menggunakan uji statistik $F$ dan uji statistik t. Uji statistik $\mathrm{F}$ digunakan untuk mengetahui apakah kelima variabel independen secara bersama-sama berpengaruh terhadap variabel dependen. Sedangkan uji statistik $t$ digunakan untuk mengetahui pengaruh satu variabel independen secara individual dalam menerangkan variasi variabel dependen. 


\section{HASIL DAN PEMBAHASAN}

Statistik deskriptif merupakan penjelasan mengenai data yang digunakan dalam penelitian, yang terdiri dari jumlah sampel yang diteliti, nilai rata-rata (mean), nilai minimum, nilai maksimum, dan standar deviasi. Berikut ini adalah hasil statistik deskripsi data

Tabel 1 Statistik Deskripsi

\begin{tabular}{lccccc}
\hline & Mean & Minimum & Maximum & Std. Deviation & N \\
\hline Harga Saham & 6433,5 & 400 & 26200 & 8267,7283 & 30 \\
Likuiditas & 148,2281 & 44,6190 & 481,9256 & 93,51522 & 30 \\
Solvabilitas & 99,6517 & 16,3104 & 245,5200 & 72,48878 & 30 \\
Profitabilitas & 18,2817 & 2,8019 & 29,6525 & 7,27800 & 30 \\
Rasio Pasar & 399,8405 & 6,0101 & 1589,9050 & 499,6538 & 30 \\
Uk. Perusahaan & 29,6338 & 28,6073 & 30,6894 & 0,60762 & 30 \\
\hline
\end{tabular}

Sumber : Data Sekunder (Data diolah)

Berdasarkan diatas, dapat dijelaskan bahwa banyaknya data (jumlah $\mathrm{N}$ ) yang digunakan dalam penelitian ini sebanyak 30 data, jumlah tersebut merupakan jumlah sampel perusahaan subsektor perkebunan yang terdaftar di Bursa Efek Indonesia selama periode penelitian pada tahun 2010 sampai dengan 2014.

Nilai rata-rata harga saham selama periode penelitian tahun 2010 sampai dengan 2014 bernilai sebesar Rp6433,5 dengan standar deviasi sebesar 8267,7283. Nilai minimum harga saham dimiliki oleh PT. BW Plantation Tbk dengan nilai sebesar Rp400,00. Sedangkan nilai maksimum harga saham sebesar Rp26.200,00 dimiliki oleh PT. Astra Agro Lestari Tbk.

Variabel likuiditas pada tahun 2010 sampai dengan 2014 memiliki nilai rata-rata 148,2281 dengan standar deviasi 93,51522. Nilai minimum likuiditas dimiliki oleh PT. BW Plantation Tbk dengan nilai 44,6190. Sedangkan nilai maksimum likuiditas dimiliki oleh PT. PP London Sumatra Indonesia Tbk dengan nilai sebesar 481,9256.

Pada tahun 2010 sampai dengan 2014, variabel solvabilitas memiliki nilai rata-rata 99,6517 dengan standar deviasi 72,48878. Rasio solvabilitas terendah dimiliki oleh PT. PP London Sumatra Indonesia Tbk dengan nilai sebesar 16,3104. Sedangkan rasio solvabilitas teringgi dimiliki oleh PT. Tunas
Baru Lampung Tbk dengan nilai sebesar 245,5200.

Variabel profitabilitas pada tahun 2010 sampai dengan 2014 memiliki nilai rata-rata 18,2817 dengan standar deviasi 7,27800. Nilai minimum profitabilitas dimiliki oleh PT. BW Plantation Tbk dengan nilai sebesar 2,8019. Sementara itu, nilai maksimum profitabilitas bernilai sebesar 29,6525. Nilai tersebut dimiliki oleh PT. Astra Agro Lestari Tbk.

Variabel rasio pasar memiliki nilai rata-rata 399,8405 dengan standar deviasi 499,6538. Rasio pasar terendah dimiliki oleh PT. BW Plantation Tbk dengan nilai 6,0101 . Sementara itu, nilai maksimum rasio pasar dimiliki oleh PT. Astra Agro Lestari Tbk dengan nilai sebesar 1589,9050.

Variabel ukuran perusahaan memiliki nilai rata-rata 29,6338 dengan standar deviasi 0,60762. Nilai terendah dari ukuran perusahaan adalah sebesar 28,6073. Nilai tersebut dimiliki oleh PT. BW Plantation Tbk. Sedangkan nilai maksimum ukuran perusahaan dimiliki oleh PT. SMART Tbk dengan nilai sebesar 30,6894.

\section{Uji Asumsi Klasik \\ Uji Normalitas}

Berikut hasil uji normalitas data yang berkaitan dengan penelitian ini. 


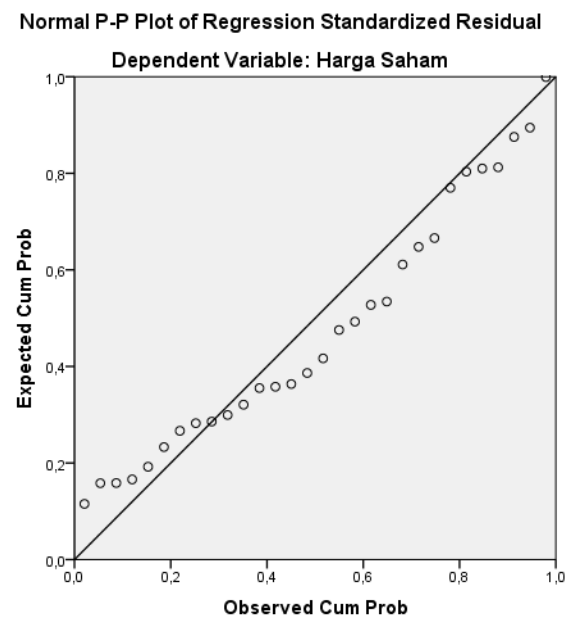

\section{Gambar 1. Hasil Uji Normalitas}

Berdasarkan Gambar diatas, dapat disimpulkan bahwa data yang digunakan dalam penelitian ini berdistribusi normal. Hal itu terlihat dari penyebaran titik yang mengikuti arah dan menyebar di sekitar garis diagonal. Selain dari grafik di atas, penelitian ini menggunakan uji Sample KolmogorovSmirnov untuk membuktikan bahwa data yang digunakan dalam penelitian ini berdistribusi normal. Berikut hasil uji One-Sample Kolmogorov-Smirnov

Tabel 2. Hasil Uji Normalitas

\begin{tabular}{|c|c|c|c|c|c|c|c|}
\hline \multicolumn{8}{|c|}{ One-Sample Kolmogorov-Smirnov Test } \\
\hline & & Likuiditas & Solvabilitas & Profitabilitas & Rasio Pasar & $\begin{array}{c}\text { Uk. } \\
\text { Perusahaan }\end{array}$ & $\begin{array}{l}\text { Harga } \\
\text { Saham }\end{array}$ \\
\hline \multicolumn{2}{|c|}{$\mathrm{N}$} & 30 & 30 & 30 & 30 & 30 & 30 \\
\hline \multirow{2}{*}{$\begin{array}{c}\text { Normal } \\
\text { Parameters }^{\mathrm{a}, \mathrm{b}}\end{array}$} & Mean & 148,2281 & 99,6517 & 18,2817 & 5,1967 & 29,6338 & 7,9808 \\
\hline & $\begin{array}{c}\text { Std. } \\
\text { Deviation }\end{array}$ & 93,51522 & 72,48878 & 7,27800 & 1,38272 & ,60762 & 1,30806 \\
\hline \multirow{3}{*}{$\begin{array}{l}\text { Most Extreme } \\
\text { Differences }\end{array}$} & Absolute &, 155 &, 156 &, 121 & 076 & 104 & 120 \\
\hline & Positive &, 155 &, 156 & ,068 & 074 & ,082 & 120 \\
\hline & Negative &,- 134 &,- 125 &,- 121 &,- 076 &,- 104 &,- 094 \\
\hline \multicolumn{2}{|c|}{ Kolmogorov-Smirnov Z } & 847 & ,856 & ,665 & ,415 & ,570 & ,660 \\
\hline \multicolumn{2}{|c|}{ Asymp. Sig. (2-tailed) } & , 470 & ,457 & ,768 & ,995 & ,901 & ,777 \\
\hline & & a. Test c & listribution & Normal. & & & \\
\hline & & b. $\mathrm{C}$ & lculated fro & data. & & & \\
\hline
\end{tabular}

Sumber: Output SPSS Statistics 20.0 (Data diolah)

Tabel berikut memperlihatkan bahwa likuiditas memiliki nilai KolmogorovSmirnov Z sebesar 0,847 dan nilai signifikansi sebesar 0,470>0,05. Solvabilitas memiliki nilai Kolmogorov-Smirnov Z sebesar 0,856 dengan signifikansi sebesar 0,457>0,05. Profitabilitas memiliki nilai KolmogorovSmirnov Z sebesar 0,665 dengan signifikansi sebesar 0,768>0,05. Rasio pasar memiliki nilai Kolmogorov-Smirnov $\mathrm{Z}$ sebesar 0,415 dengan signifikansi sebesar $0,995>0,05$. Ukuran perusahaan memiliki nilai Kolmogorov-Smirnov Z sebesar 0,570 dengan signifikansi sebesar 0,901. Dan nilai Kolmogorov-Smirnov Z untuk harga saham bernilai sebesar 0,660 dengan signifikansi 
NITA FITRIANI ARIFIN \& SILVIANA AGUSTAMI/ Pengaruh Likuiditas, Solvabilitas, Profitabilitas, Rasio Pasar, Dan Ukuran Perusahaan Terhadap Harga Saham...

sebesar 0,777 >0,05. Dengan demikian, datadata yang digunakan dalam penelitian ini berdistribusi normal.

\section{Uji Multikolinieritas}

Berikut hasil penelitian uji multikolinieritas yang dilakukan dalam penelitian ini.

Tabel 3 Hasil Uji Multikolinieritas

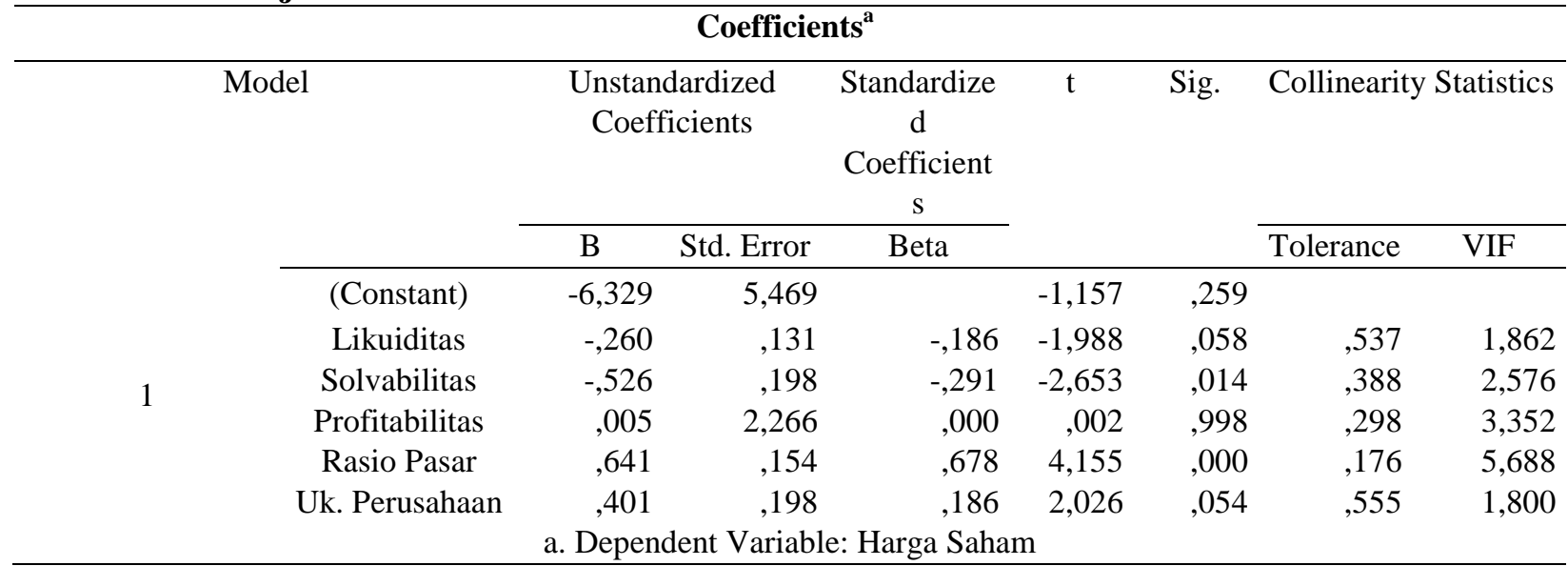

Sumber : Output SPSS Statistics 20.0 (Data diolah)

Tabel diatas memperlihatkan bahwa nilai tolerance dari variabel-variabel independen bernilai lebih dari 0,10. Hasil perhitungan nilai tolerance tersebut menunjukkan bahwa dalam penelitian ini tidak terdapat korelasi antarvariabel independen. Hal yang sama juga ditunjukkan oleh hasil perhitungan nilai VIF dimana variabel-variabel independen memiliki nilai VIF kurang dari 10, dengan demikian tidak terdapat korelasi antarvariabel independen. Berdasarkan hasil pengujian tersebut, dapat disimpulkan bahwa data yang digunakan dalam penelitian ini terbebas dari masalah multikolinieritas.

\section{Uji Heteroskedastisitas}

Berikut ini hasil dari uji heteroskedastisitas yang dilakukan dalam penelitian ini.

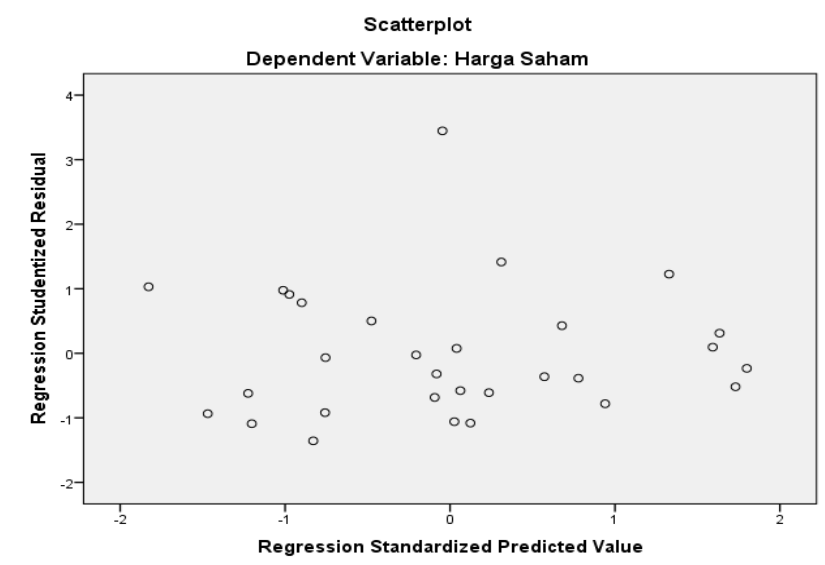

Sumber : Output SPSS Statistics 20.0 (Data diolah)

\section{Gambar 2. Uji Heteroskedastisitas dengan Grafik Scatterplot}


Berdasarkan gambar di atas, terlihat bahwa titik-titik membentuk suatu pola yang tidak jelas dan menyebar secara acak baik di atas maupun di bawah angka nol pada sumbu Y. Dengan demikian, dapat disimpulkan tidak terjadi heteroskedastisitas atau tidak terjadi kesamaan residual dari satu pengamatan ke pengamatan yang lain dalam penelitian ini sehingga model regresi ini layak digunakan untuk memprediksi harga saham.

Selain melihat grafik scatterplot, penelitian ini menggunakan uji Glejser dalam mendeteksi ada tidaknya heteroskedastisitas. Berikut ini hasil dari uji Glejser yang dilakukan dengan bantuan software IBM SPSS Statistics versi 20.0 for windows.

Tabel 4. Hasil dari uji Glejser.

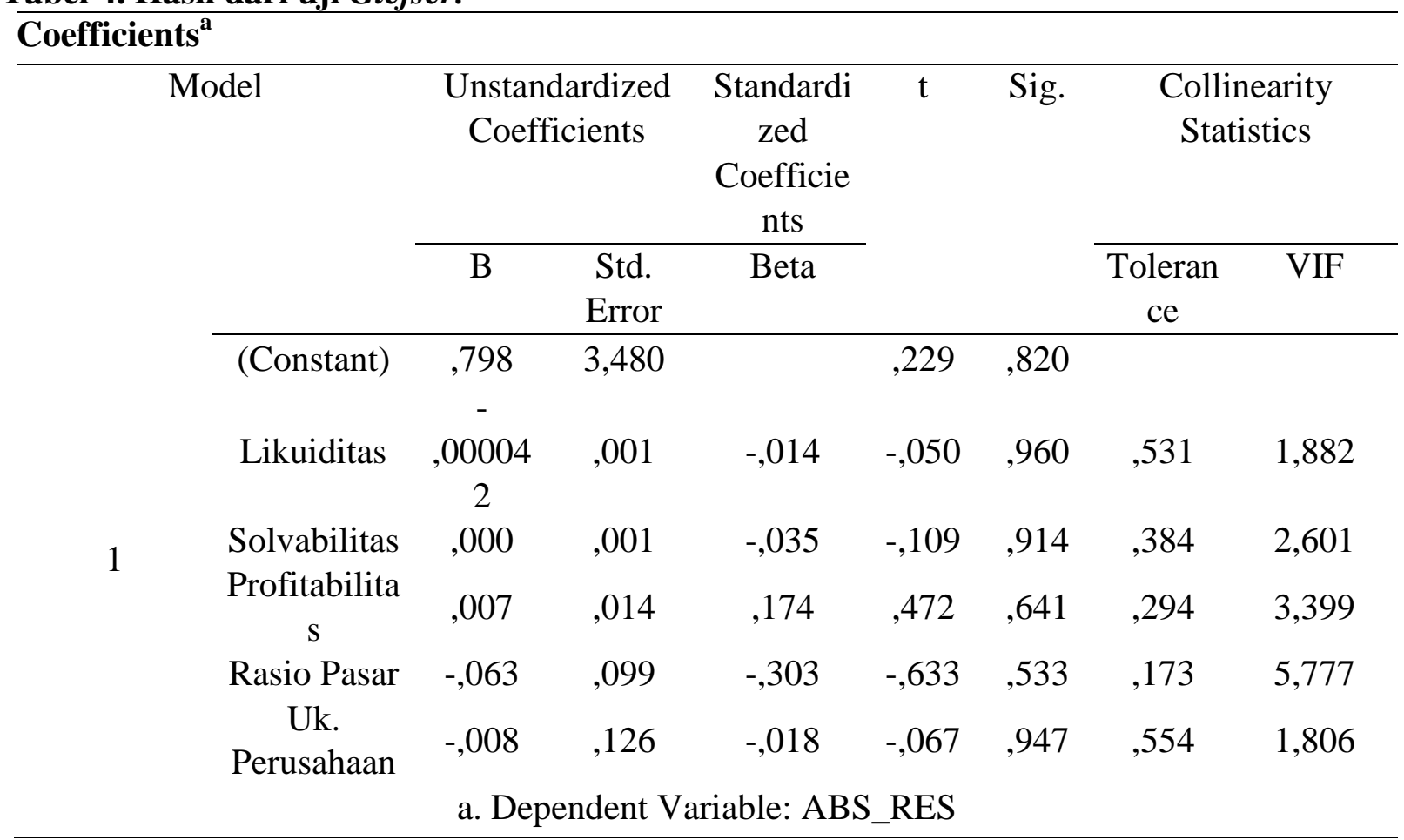

Sumber : Output SPSS Statistics 20.0 (Data diolah)

Berdasarkan tabel diatas, terlihat bahwa variabel-variabel independen dalam penelitian ini memiliki nilai signifikansi $\alpha$ lebih tinggi dibandingkan $\alpha$ yang ditetapkan, yaitu 0,05 . Dengan demikian dapat disimpulkan bahwa kelima variabel independen bersifat homogen dan terbebas dari masalah heteroskedastisitas.

\section{Uji Autokorelasi}

Berikut ini hasil pengujian autokorelasi yang dilakukan dalam penelitian ini dengan menggunakan uji Durbin-Watson. 
NITA FITRIANI ARIFIN \& SILVIANA AGUSTAMI/ Pengaruh Likuiditas, Solvabilitas, Profitabilitas, Rasio Pasar, Dan Ukuran Perusahaan Terhadap Harga Saham...

Tabel 5. Uji Autokorelasi

\begin{tabular}{cccccc}
\hline & \multicolumn{5}{c}{ Model Summary $^{\mathbf{b}}$} \\
\hline Model & $\mathrm{R}$ & $\mathrm{R}$ Square & $\begin{array}{c}\text { Adjusted R } \\
\text { Square }\end{array}$ & $\begin{array}{c}\text { Std. Error of } \\
\text { the Estimate }\end{array}$ & Durbin-Watson \\
\hline 1 &, $942^{\mathrm{a}}$ &, 887 &, 864 &, 48299 & 1,302
\end{tabular}

a. Predictors: (Constant), Uk. Perusahaan, Likuiditas, Solvabilitas, Profitabilitas, Rasio Pasar

b. Dependent Variable: Harga Saham

Sumber: Output SPSS Statistics 20.0 (Dat
Tabel diatas menunjukkan bahwa angka
D-W dalam penelitian ini bernilai 1,302.
Angka ini berada diantara -2 sampai +2 .
Berdasarkan hasil tersebut, dapat disimpulkan
bahwa penelitian ini terbebas dari masalah
autokorelasi.

Uji Hipotesis

Analisis Koefisien Determinasi

Pengujian ini dilakukan untuk mengetahui seberapa besar pengaruh variabel independen yang terdiri dari likuiditas, solvabilitas, profitabilitas, rasio pasar, dan ukuran perusahaan. Berikut ini hasil dari uji koefisien determinasi.

Tabel 6. Hasil Pengujian Koefisien Determinasi

\begin{tabular}{|c|c|c|c|c|c|c|c|c|c|c|}
\hline \multicolumn{11}{|c|}{ Model Summary $^{b}$} \\
\hline \multirow[t]{2}{*}{ Model } & \multirow[t]{2}{*}{$\mathrm{R}$} & \multirow{2}{*}{$\begin{array}{c}\mathrm{R} \\
\text { Square }\end{array}$} & \multirow{2}{*}{$\begin{array}{l}\text { Adjusted } \\
\text { R Square }\end{array}$} & \multirow{2}{*}{$\begin{array}{l}\text { Std. Error of } \\
\text { the Estimate }\end{array}$} & \multicolumn{5}{|c|}{ Change Statistics } & \multirow[t]{2}{*}{ Durbin-Watson } \\
\hline & & & & & $\begin{array}{l}\text { R Square } \\
\text { Change }\end{array}$ & $\begin{array}{c}\text { F } \\
\text { Chang } \\
\text { e }\end{array}$ & df1 & df 2 & $\begin{array}{c}\text { Sig. F } \\
\text { Change }\end{array}$ & \\
\hline \multirow[t]{2}{*}{1} & $\begin{array}{r}942 \\
\mathrm{a}\end{array}$ & ,887 & ,864 & 48299, & ,887 & 37,741 & 5 & 24 &, 000 & 1,302 \\
\hline & a. Pred & ictors: (C & Oonstant), U & $\begin{array}{l}\text { k. Perusahaan, } \\
\text { b. Dependent }\end{array}$ & $\begin{array}{l}\text { Profitabilita } \\
\text { Variable: Ha }\end{array}$ & $\begin{array}{l}\text { s, Likuidi } \\
\text { rga Sahan }\end{array}$ & tas, Sc & lvabili & tas, Rasio & Pasar \\
\hline
\end{tabular}

Sumber : Output SPSS Statistics 20.0 (Data diolah)

Berdasarkan tabel berikut, diperoleh nilai koefisien determinasi atau $\mathrm{R}^{2}$ sebesar 0,887 atau sama dengan $88,7 \%$. Hal ini menunjukkan bahwa variabel harga saham dapat dijelaskan oleh variabel independen yang terdiri dari likuiditas, solvabilitas, profitabilitas, rasio pasar, dan ukuran perusahaan sebesar $88,7 \%$. Sedangkan sisanya sebesar $11,3 \%$ dapat dijelaskan oleh variabelvariabel lain diluar model penelitian ini.

Analisis Regresi Linier Berganda Berikut adalah tabel coefficients $^{a}$ yang menunjukkan hasil perhitungan analisis regresi berganda dengan menggunakan software IBM SPSS Statistics versi 20.0 for windows.

Tabel 7. Hasil Analisis Regresi Linier Berganda

\begin{tabular}{|c|c|c|c|c|c|c|c|c|}
\hline \multicolumn{9}{|c|}{ Coefficients $^{\mathrm{a}}$} \\
\hline & \multirow[t]{2}{*}{ Model } & \multicolumn{2}{|c|}{$\begin{array}{c}\text { Unstandardized } \\
\text { Coefficients }\end{array}$} & \multirow{2}{*}{$\begin{array}{c}\text { Standardize } \\
\mathrm{d} \\
\text { Coefficient } \\
\mathrm{s}\end{array}$} & \multirow[t]{2}{*}{$\mathrm{t}$} & \multirow[t]{2}{*}{ Sig. } & \multicolumn{2}{|c|}{ Collinearity Statistics } \\
\hline & & $\mathrm{B}$ & Std. Error & & & & Tolerance & VIF \\
\hline \multirow{2}{*}{1} & (Constant) & $-6,329$ & 5,469 & & $-1,157$ & 259 & & \\
\hline & Likuiditas &,- 260 &, 131 &,- 186 & $-1,988$ &, 058 &, 537 & 1,862 \\
\hline
\end{tabular}




\begin{tabular}{|c|c|c|c|c|c|c|c|}
\hline Solvabilitas &,- 526 & , 198 &,- 291 & $-2,653$ & ,014 & ,388 & 2,576 \\
\hline Profitabilitas & ,005 & 2,266 & 000 &, 002 & ,998 & ,298 & 3,352 \\
\hline Rasio Pasar & ,641 & , 154 & ,678 & 4,155 & ,000 &, 176 & 5,688 \\
\hline Uk. Perusahaan & ,401 & , 198 & , 186 & 2,026 &, 054 & ,555 & 1,800 \\
\hline
\end{tabular}

Sumber : Output SPSS Statistics 20.0 (Data diolah)

Tabel 4.15 di atas menunjukkan perhitungan analisis regresi linier berganda. Hasil dari uji coefficients, pada uji regresi linier berganda keseluruhan pengaruh likuiditas, solvabilitas, profitabilitas, rasio pasar, dan ukuran perusahaan terhadap harga saham dikemukakan dengan nilai (constant $)=$ $-6,329, \beta_{1} X_{1}=-0,260, \beta_{2} X_{2}=-0,526, \beta_{3} X_{3}=$ $0,005, \quad \beta_{4} X_{4}=0,641, \quad \beta_{5} X_{5}=0,401$. Berdasarkan keterangan tersebut, maka dapat dituliskan persamaan regresi linier berganda untuk penelitian ini sebagai berikut.

$$
\begin{gathered}
Y=-6,329-0,260 \text { Likuiditas }-0,526 \text { Solvabilitas }+ \\
0,005 \text { Profitabilitas }+0,641_{\text {Rasio Pasar }}-0,401 \text { Ukuran } \\
\text { Perusahaan }
\end{gathered}
$$

Berdasarkan persamaan regresi diatas maka dapat dijelaskan sebagai berikut.

$\alpha=-6,329$ merupakan nilai konstanta, artinya jika tidak terdapat variabel likuiditas, solvabilitas, profitabilitas, rasio pasar, dan ukuran perusahaan maka nilai harga saham sebesar -6,329 satuan.

$\beta_{1}=-0,260$, variabel likuiditas bertanda negatif yang artinya likuiditas memiliki hubungan yang berlawanan dengan harga saham, dimana setiap likuiditas yang diproksikan dengan current ratio mengalami kenaikan sebesar 1 satuan akan menyebabkan penurunan harga saham sebesar $-0,260$ satuan dengan asumsi nilai variabel lainnya masih tetap konstan.

$\beta_{2}=-0,526$, variabel solvabilitas bertanda negatif yang artinya solvabilitas memiliki hubungan yang berlawanan dengan harga saham, dimana setiap solvabilitas yang diproksikan dengan debt equity ratio mengalami kenaikan sebesar 1 satuan maka akan menyebabkan penurunan harga saham sebesar -0,526 satuan dengan asumsi nilai variabel lainnya masih tetap konstan.

$\beta_{3}=0,005$, variabel profitabilitas bertanda positif yang artinya profitabilitas memiliki hubungan yang searah dengan harga saham, dimana setiap profitabilitas yang diproksikan dengan return on equity mengalami kenaikan sebesar 1 satuan akan menyebabkan kenaikan harga saham sebesar 0,005 satuan dengan asumsi nilai variabel lainnya masih tetap konstan.

$\beta_{4}=0,641$, variabel rasio pasar bertanda positif yang artinya rasio pasar memiliki hubungan yang searah dengan harga saham, dimana setiap rasio pasar yang diproksikan dengan earning per share mengalami kenaikan sebesar 1 satuan akan menyebabkan kenaikan harga saham sebesar 0,641 satuan dengan asumsi nilai variabel lainnya masih tetap konstan.

$\beta_{5}=0,401$, variabel ukuran perusahaan bertanda positif yang artinya ukuran perusahaan memiliki hubungan yang searah dengan harga saham, dimana setiap ukuran perusahaan mengalami kenaikan sebesar 1 satuan maka akan menyebabkan kenaikan harga saham sebesar 0,401 satuan dengan asumsi nilai variabel lainnya masih tetap konstan.

\section{Uji Statistik F}

Berikut ini adalah hasil dari perhitungan uji $\mathrm{F}$ 
Tabel 8. Hasil Uji F

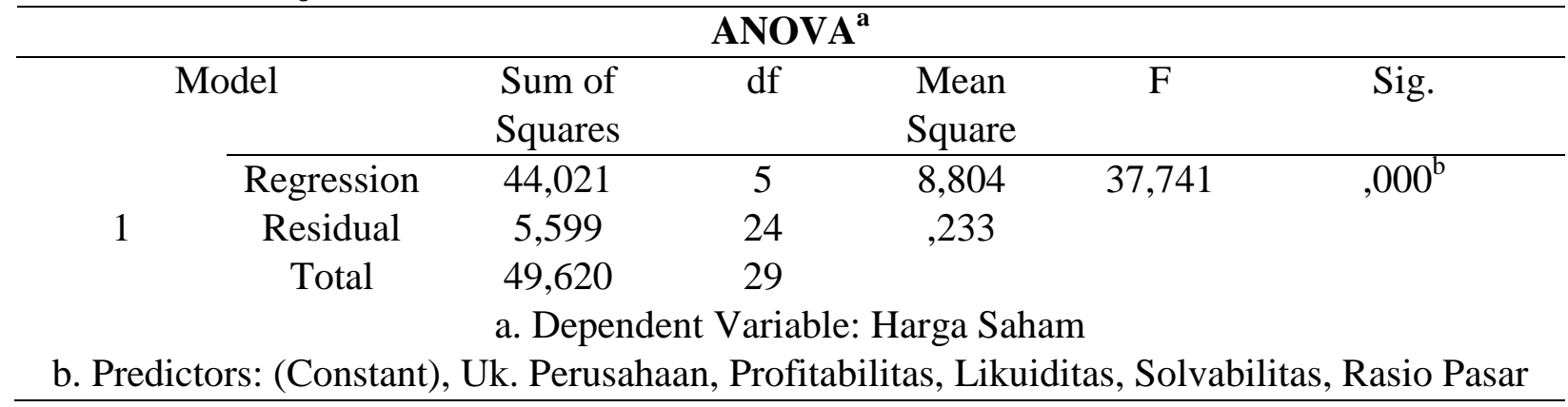

Sumber: Output SPSS Statistics 20.0 (Data diolah)

Berdasarkan tabel 4.16 , hasil uji $\mathrm{F}$ menunjukkan bahwa hasil $F_{\text {hitung }}$ bernilai sebesar 37,741 dengan tingkat signifikansi 0,000 . Oleh karena nilai $F_{\text {hitung }}$ sebesar 37,741 lebih besar dari nilai $F_{\text {tabel }}$ sebesar 2,62 dengan tingkat signifikansi 0,000 yang berarti di bawah 0,05 atau 5\%, itu menjelaskan bahwa $\mathrm{H}_{0-1}$ ditolak, artinya variabel likuiditas, solvabilitas, profitabilitas, rasio pasar, dan ukuran perusahaan secara bersama-sama memiliki pengaruh yang signifikan terhadap variabel harga saham.

\section{Uji Statistik t}

Berikut ini adalah hasil dari perhitungan uji statistik t.

\section{Tabel 9. Hasil Uji Statistik}

\begin{tabular}{|c|c|c|c|c|c|c|}
\hline \multicolumn{7}{|c|}{ Coefficients $^{\mathbf{a}}$} \\
\hline & \multirow[t]{2}{*}{ Model } & \multicolumn{2}{|c|}{$\begin{array}{l}\text { Unstandardized } \\
\text { Coefficients }\end{array}$} & $\begin{array}{c}\text { Standardized } \\
\text { Coefficients }\end{array}$ & $\mathrm{t}$ & Sig. \\
\hline \multirow{7}{*}{1} & & $\mathrm{~B}$ & Std. Error & Beta & & \\
\hline & (Constant) & $-6,329$ & 5,469 & & $1, \overline{157}$ & ,259 \\
\hline & Likuiditas &,- 260 & ,131 &,- 186 & $\begin{array}{c}- \\
1,988\end{array}$ &, 058 \\
\hline & Solvabilitas &,- 526 & ,198 &,- 291 & $2, \overline{653}$ &, 014 \\
\hline & Profitabilitas & ,005 & 2,266 & ,000 & ,002 & ,998 \\
\hline & Rasio Pasar & ,641 & ,154 & ,678 & 4,155 &, 000 \\
\hline & $\begin{array}{c}\text { Uk. } \\
\text { Perusahaan }\end{array}$ & ,401 & ,198 & , 186 & 2,026 & ,054 \\
\hline
\end{tabular}

Sumber : Output SPSS Statistics 20.0 (Data diolah)

Berdasarkan tabel 4.17 , hasil uji statistik $t$ menunjukkan bahwa variabel likuiditas yang diproksikan dengan current ratio memiliki nilai signifikansi sebesar 0,058 yang berarti lebih besar dari 0,05 $(0,058>0,05)$ sehingga likuiditas tidak pengaruh signifikan terhadap harga saham.
Nilai koefisien regresi yang dimiliki likuiditas bernilai $-0,260$ yang berarti variabel likuiditas memiliki pengaruh yang berlawanan dengan harga saham. Dengan demikian, dapat disimpulkan bahwa $\mathrm{H}_{\mathrm{a}-2}$ yang menyatakan terdapat pengaruh positif antara likuiditas terhadap harga saham ditolak. 
Variabel solvabilitas yang diproksikan dengan debt equity ratio memiliki nilai signifikansi sebesar $0,014(0,014<0,05)$, hal ini dapat diartikan bahwa solvabilitas berpengaruh signifikan terhadap harga saham. Nilai koefisien regresi yang dimiliki solvabilitas sebesar -0,526 yang berarti variabel solvabilitas memiliki pengaruh yang berlawanan dengan harga saham. Dengan demikian, $\mathrm{H}_{\mathrm{a}-3}$ yang menyatakan terdapat pengaruh negatif antara solvabilitas terhadap harga saham diterima.

Variabel profitabilitas yang diproksikan dengan return on equity memiliki nilai signifikansi sebesar 0,998 dimana nilai tersebut lebih besar dari 0,05 sehingga dapat diartikan bahwa profitabilitas tidak berpengaruh secara signifikan terhadap harga saham. Nilai koefisien regresi yang dimiliki profitabilitas sebesar 0,005 yang berarti profitabilitas memiliki pengaruh yang searah dengan harga saham. Berdasarkan hasil tersebut, dapat disimpulkan bahwa $\mathrm{H}_{\mathrm{a}-4}$ yang menyatakan terdapat pengaruh positif antara profitabilitas terhadap harga saham diterima.

Variabel rasio pasar yang diproksikan dengan earning per share memiliki nilai signifikansi sebesar 0,000 yang berarti nilainya lebih kecil dari $0,05(0,000<0,05)$ sehingga dapat diartikan bahwa rasio pasar berpengaruh signifikan terhadap harga saham. Koefisien regresi yang dimiliki oleh rasio pasar bernilai sebesar 0,641 yang berarti rasio pasar memiliki pengaruh yang searah dengan harga saham. Dengan demikian, $\mathrm{H}_{\mathrm{a}-5}$ yang menyatakan terdapat pengaruh positif antara rasio pasar terhadap harga saham diterima.

Variabel ukuran perusahaan memiliki nilai signifikansi sebesar 0,054 dimana nilai tersebut berada sedikit diatas $0,05(0,054>$ 0,05) sehingga dapat diartikan bahwa ukuran perusahaan tidak berpengaruh signifikan terhadap harga saham. Sedangkan nilai koefisien regresi yang dimiliki ukuran perusahaan bernilai 0,401 yang berarti ukuran perusahaan memiliki pengaruh yang searah dengan harga saham. Berdasarkan hasil tersebut, dapat disimpulkan bahwa $\mathrm{H}_{\mathrm{a}-6}$ yang menyatakan bahwa ukuran perusahaan berpengaruh positif terhadap harga saham diterima.

\section{SIMPULAN}

Berdasarkan hasil penelitian yang dijelaskan pada bab sebelumnya, peneliti dapat menarik beberapa kesimpulan berdasarkan penelitian yang dilakukan tentang pengaruh likuiditas, solvabilitas, profitabilitas, rasio pasar, dan ukuran perusahaan terhadap harga saham pada perusahaan subsektor perkebunan pada tahun 2010-2014, diantaranya sebagai berikut: Berdasarkan hasil pengujian, variabel likuiditas, solvabilitas, profitabilitas, rasio pasar, dan ukuran perusahaan secara bersama-sama memiliki pengaruh yang signifikan terhadap variabel harga saham; Variabel likuiditas yang diproksikan dengan current ratio memiliki pengaruh yang negatif terhadap harga saham. Dengan demikian, ketika likuiditas meningkat maka harga saham akan menurun. Sebaliknya, jika likuiditas menurun, maka harga saham akan mengalami peningkatan; Variabel solvabilitas yang diproksikan dengan debt to equity ratio memiliki pengaruh yang negatif terhadap harga saham. Berdasarkan hasil tersebut, solvabilitas memiliki pengaruh yang berlawanan dengan harga saham, dimana ketika solvabilitas menurun maka harga saham akan meningkat sedangkan ketika solvabilitas meningkat maka harga saham akan menurun; Variabel profitabilitas yang diproksikan dengan return on equity memiliki pengaruh positif terhadap harga saham. Berdasarkan hasil tersebut, ketika profitabilitas meningkat maka harga saham akan meningkat dan ketika profitabilitas menurun maka harga saham akan ikut menurun; Variabel rasio pasar yang diproksikan dengan earning per share memiliki pengaruh yang positif terhadap harga saham. Dengan demikian, apabila rasio pasar mengalami peningkatan maka harga saham akan ikut meningkat dan ketika rasio pasar menurun maka harga saham pun ikut menurun; Variabel ukuran perusahaan memiliki pengaruh yang positif terhadap 
harga saham. Dengan demikian, apabila ukuran perusahaan mengalami peningkatan maka harga saham akan ikut meningkat dan ketika ukuran perusahaan menurun maka harga saham pun ikut menurun.

\section{SARAN}

Berdasarkan hasil penelitian yang telah dilakukan, penulis dapat mengemukakan saran agar penelitian selanjutnya sebaiknya perlu menambahkan rasio keuangan lainnya sebagai variabel independen dan menambahkan faktor-faktor lainnya di luar rasio keuangan sebagai variabel independen, seperti faktor mikro seperti pemasaran, penjualan, serta pendanaan dan faktor makro ekonomi seperti inflasi, nilai tukar (kurs), suku bunga, jumlah uang beredar dan lain sebagainya sebagai prediktor terhadap harga saham karena sangat dimungkinkan faktorfaktor tersebut berpengaruh lebih kuat terhadap harga saham. Penelitian selanjutnya sebaiknya perlu menambahkan rentang waktu yang lebih panjang sehingga nantinya diharapkan hasil yang diperoleh dapat memperluas penelitian serta menghasilkan analisis yang lebih baik. (Arista \& Astohar 2012)(Almas 2007)(Ang 1997)

\section{DAFTAR PUSTAKA}

Almas, H., 2007. Pengaruh Faktor Fundamental dan Risiko Sistematik Terhadap Harga Saham Properti di Bursa Efek Jakarta. Universitas Sumatra Utara.

Anoraga, Pandji \& Puji Pakarti. 2003. Pengantar Pasar Modal. Jakarta: Rineka Cipta. 2008. Pengantar Pasar Modal. Jakarta: Rineka Cipta.

Ang, R., 1997. Buku Pintar Pasar Modal I Edition, Jakarta: Media Soft Indonesia.

Arista, D. \& Astohar, 2012. Analisis Faktorfaktor yang Mempengaruhi Return Saham (Studi pada Perusahaan Manufaktur yang Go Public di BEI periode tahun 2005-2009). Jurnal Ilmu Manajemen dan Akuntansi
Terapan, 3(Mei).

Belkaoui, Ahmed Riahi. 2011. Teori Akuntansi Edisi 5. Jakarta: Salemba Empat.

Bodie, Kane, Alex \& Marcus. 2003. Essentials of Investments. Fifth Edition. New York: Mc Graw Hill Companies.

Brigham, E. F. \& J. F. Weston. 1997. Dasardasar Manajemen Keuangan Jilid 2 Edisi Kesembilan. Jakarta: Erlangga.

Brigham, Eugene F \& Joel F. Houston. 2006. Dasar-dasar Manajemen Keuangan Edisi 10. Jakarta: Salemba Empat. 2011. Essential of Financial Management 11 Edition Buku 2. Horcourt College United States of America.

Darmadji, Tjiptono \& Hendy M. Fakhruddin, 2006. Pasar Modal Di Indonesia, Pendekatan Tanya Jawab Edisi Kedua. Jakarta: Salemba Empat.

Darsono \& Ashari. 2005. Pedoman Praktis Memahami Laporan Keuangan. Yogyakarta: Penerbit ANDI.

Djarwanto. 2004. Pokok-pokok Analisa Laporan Keuangan Edisi Kedua Cetakan Pertama. Yogyakarta: BPFEYogyakarta.

Fahmi, Irham \& Yovi Lavianti Hadi. 2009. Teori Portofolio dan Analisis Investasi Teori dan Soal Jawab. Bandung: Alfabeta.

Fakhruddin, M \& Hardianto Sopian. 2001. Perangkat dan Model Analisa Investasi di Pasar Modal. Jakarta: PT. Elex Media Komputindo Gramedia.

Francis, Jack C. 1988. Management of Investment 2nd ed. International Editions Financial Series. Singapore : McGraw Hill.

Gitman, Lawrence J. 2003. Principles of Managerial Finance 10th edition. International Editions Financial Series. Boston: Addison-Wesley.

Ghozali, Imam. 2005. Aplikasi Analisis Multivariate Dengan Program SPSS. Semarang: Badan Penerbit Universitas Diponegoro. 2007. Aplikasi Analisis 
Multivariate Dengan Program SPSS. Semarang: Badan Penerbit Universitas Diponegoro.

Harahap, Sofyan Syafri. 1999. Analisa Kritis Atas Laporan Keuangan. Jakarta: PT. Raja Grafindo Persada.

Harahap, Sofyan Syafri. 2007. Analisis Kritis Atas Laporan Keuangan. Jakarta : PT Raja Grafindo Persada.

Harahap, Sofyan Syafri. 2009. Teori Akuntansi. Jakarta: PT Raja Grafindo Persada.

Husnan, Suad. 2003. Dasar-dasar Teori Portofolio dan Analisis Sekuritas. Yogyakarta: UPP AMP YKPN.

Ikatan Akuntan Indonesia. 2002. Standar Akuntansi Keuangan. Jakarta: Salemba Empat.

Ikhsan, Arfan \& I. B. Teddy Prianthara. 2009. Akuntansi untuk Manajer. Yogyakarta: Graha Ilmu.

Indriantoro, Nur \& Bambang Supomo. 2002. Metodologi Penelitian Bisnis Untuk Akuntansi \& Manajemen. Yogyakarta: BPFE-YOGYAKARTA.

Iskandar, Alwi Z. 2003. Pasar Modal Teori dan Aplikasi Edisi Pertama. Jakarta: Yayasan Pancur Siwah.

Jogiyanto, Hartono. 2000. Teori Portofolio dan Analisis Investasi. Yogyakarta: BPFE.

2003. Teori Portofolio dan Analisis Investasi. Yogyakarta: BPFE. . 2008. Teori Portofolio dan Analisis Investasi. Yogyakarta: BPFE.

Kamil, Ahmad \& Antonius Herusetya. 2012. Pengaruh Karakteristik Perusahaan Terhadap Luas Pengungkapan Kegiatan Corporate Social Responsibility. Media Riset Akuntansi. 3(1).

Kartika, Andi. 2009. Faktor-faktor yang Memepengaruhi Kelengkapan Pengungkapan Laporan Keuangan Pada Perusahaan Manufaktur yang Terdaftar Di Bursa Efek Indonesia. Kajian Akuntansi. Volume 1(1).

Kasmir. 2008. Bank dan Lembaga Keuangan Lainnya. Jakarta: PT. RajaGrafindo Persada.
Kasmir. 2008. Analisis Laporan Keuangan. Jakarta: PT. Rajawali Pers.

Kementerian Sekretariat Negara Indonesia. 2013. Prospek Perekonomian Indonesia Tahun 2013. [Online]. Tersedia

http://www.setneg.go.id/index.php?op tion $=$ com content $\&$ task $=$ view $\&$ id $=67$ 65. [2 April 2013].

Kesuma, Ali. 2009. Analisis Faktor yang Mempengaruhi Struktur Modal Serta Pengaruhnya Terhadap Harga Saham Perusahaan Real Estate yang Go Public di Bursa Efek Indonesia. Jurnal Manajemen dan Kewirausahaan 11(1). pp. 38-45.

Kieso, et al. 2008. Intermediate Edisi Keduabelas. Jakarta: Penerbit Erlangga.hal. 351-366.

Kodrat, David Sukardi \& Kurniawan Indonanjaya. 2010. Manajemen Investasi: Pendekatan Teknikal dan Fundamental untuk Analisis Saham. Yogyakarta: Graha Ilmu.

Mahrovi, Zubi. 2014. IHSG Ditutup Menguat ke 5.226 Pada Perdagangan Akhir Tahun. [Online]. Tersedia : https://www.antaranews.com/berita/4 71522/ihsg-ditutup-menguat-ke-5226pada-perdagangan-akhir-tahun. [4 Desember 2015].

Majalah Media Industri. 2013. Pertumbuhan Industri Manufaktur 2013 Ditarget 7,14\%. [Online]. Tersedia: www.kemenperin.go.id. [13 Maret 2014].

Martono \& Agus D Harjito, 2010. Manajemen Keuangan. Edisi Pertama. Yogyakarta: Ekonisia.

Pasaribu, Rowland Bismark Fernando. 2009. Kinerja Pasar dan Informasi Akuntansi Sebagai Pembentuk Portofolio Saham. Jurnal Ekonomi dan Bisnis 3(3). pp. 203-223.

Prasetya, Mellisa \& Soni Agus Irwandi. 2012. Faktor-faktor yang Mempengaruhi Pelaporan Keuangan Melalui Internet (Internet Financial Reporting) Pada Perusahaan Manufaktur Di Bursa Efek Indonesia. 
The Indonesian Accounting Review 2(2). pp. $151-158$.

Purwanta, Wiji \& Hendy Fakhruddin. 2006. Mengenal Pasar Modal. Jakarta: Salemba Empat.

Rivai, Veithzal dkk. 2013. Financial Institution Management (Manajemen Kelembagaan Keuangan): Disajikan Secara Lengkap dari Teori Hingga Aplikasi. Jakarta: Rajawali Pers.

Riyadi, Sugeng. 2012. Pertumbuhan Ekonomi Dunia Melambat, Saham Sektor Pertanian Tertekan. [Online]. Tersedia https://financeroll.co.id/news/pertumb uhan-ekonomi-dunia-melambatsaham-sektor-pertanian-tertekan/. $\quad$ [4 Desember 2015].

Rusdin. 2008. Pasar Modal. Bandung: Alfabeta.

Samsul, Mohamad. 2006. Pasar Modal \& Manajemen Portofolio. Jakarta: Penerbit Erlangga.

Santoso, Singgih. 2012. Aplikasi SPSS pada Statistik Parametrik. Jakarta: Gramedia.

Simatupang, Mangasa, 2010. Pengetahuan Praktis Investasi Saham dan Reksa Dana. Edisi Pertama. Jakarta: Mitra Wacana Media.

Sofilda, E. \& Subaedi. 2006. Pengaruh Ukuran Perusahaan dan Karakteristik Kepemilikan terhadap Harga Saham LQ45 pada Bursa Efek Jakarta. Jurnal Ekonomi Bisnis Indonesia. 2(2). pp. 1-25.

Solechan, Achmad. 2009. Pengaruh Earning, Manajemen Laba, IOS, Size dan Rasio Hutang Terhadap Return Saham Pada Perusahaan yang Go Public Di BEI. Jurnal Akuntansi dan Auditing 6(1).

Sondakh, Jullie J \& Robert Lambey. 2012. Analisis Pengaruh Rasio CR, DER, ROA, ROE, dan EPS Terhadap Harga Saham Pada Perusahaan Food \& Beverages Di Bursa Efek Indonesia. Jurnal Riset Akuntansi dan Auditing 3(2). pp. 67-79.
Sudjana. 2004. Metode Statistika. Bandung: Tarsito.

Sugiyono. 2012. Metode Penelitian Bisnis. Bandung: Alfabeta.

Sugiyono. 2009. Metode Penelitian Kuantitatif Kualitatif dan $R \& D$. Bandung: Alfabeta.

Susilowati, Yeye. 2011. Reaksi Signal Rasio Profitabilitas dan Rasio Solvabilitas Terhadap Return Saham Perusahaan (Profitability and Solvability Ratio Reaction Signal Toward Stock Return Company). Jurnal Dinamika Keuangan dan Perbankan. 3(1). pp. 17-37.

Syamsuddin, Lukman. 2009. Manajemen Keuangan Perusahaan. Jakarta: RajaGrafindo Persada.

Umar, Husein. 2008. Desain Penelitian Akuntansi Keperilakuan. Jakarta: PT. RajaGrafindo Persada.

Undang-Undang Pasar Modal No. 8 Tahun 1995

Viandita, Tamara Oca dkk. 2013. Pengaruh Debt Ratio (DR), Price to Eraning Ratio (PER), Earning Per Share (EPS), dan Size Terhadap Harga Saham (Studi pada Perusahaan Industri yang Terdaftar Di Bursa Efek Indonesia). Jurnal Administrasi Bisnis. Universitas Brawijaya.

Waspada, Ikaputera. 2010. Pengetahuan Pasar Modal dan Portfolio. Bandung: Laboratorium Pendidikan Ekonomi dan Koperasi UPI.

Weston, J. Fred \& Eugene F. Brigham. 1993. Dasar-dasar Manajemen Keuangan, Jilid 2 Edisi Kesembilan Terjemahan oleh Alfonsus Sirait, Jakarta: Erlangga.

Website Resmi Bursa Efek Indonesia. [Online]. Tersedia https://www.idx.co.id. [1 April 2016].

Weston, Brigham F.Eugene \& J. F. Houston. 2001. Manajemen Keuangan. Edisi 8. Jakarta : Penerbit Erlangga.

Widaryanti. 2011. Analisis Faktor-faktor yang Mempengaruhi Ketepatan Waktu Corporate Internet Reporting Pada Perusahaan-perusahaan yang Terdaftar Di Bursa Efek Indonesia. Jurnal Ilmu 
Manajemen dan Akuntansi Terapan, 2(2).

Wijayanti. 2010. Analisis Kinerja Keuangan dan Harga Saham Perbankan Di Bursa Efek Indonesia (BEI). Journal of Indonesian Applied Economics. 4(1). pp. 71-80.

Widoatmodjo, Sawidji. 1996. Cara Sehat Investasi di Pasar Modal. Jakarta : Jurnalindo Aksan Grafika. . 2009. Pengantar Pasar Modal Indonesia (Pengantar \& Studi Kasus). Bogor: Penerbit Ghalia Indonesia.
Zen, Sri Daryanti \& Merry Herman. 2007. Pengaruh Harga Saham, Umur Perusahaan, dan Rasio Profitabilitas Perusahaan Terhadap Tindakan Perataan Laba Yang Dilakukan Oleh Perusahaan Perbankan Yang Terdaftar Di Bursa Efek Jakarta. Jurnal Akuntansi dan Manajemen. 2(2).

Zuliarni, Sri. 2012. Pengaruh Kinerja Keuangan Terhadap Harga Saham Pada Perusahaan Mining and Mining Service Di Bursa Efek Indonesia (BEI). Jurnal Aplikasi Bisnis. 3(1). 


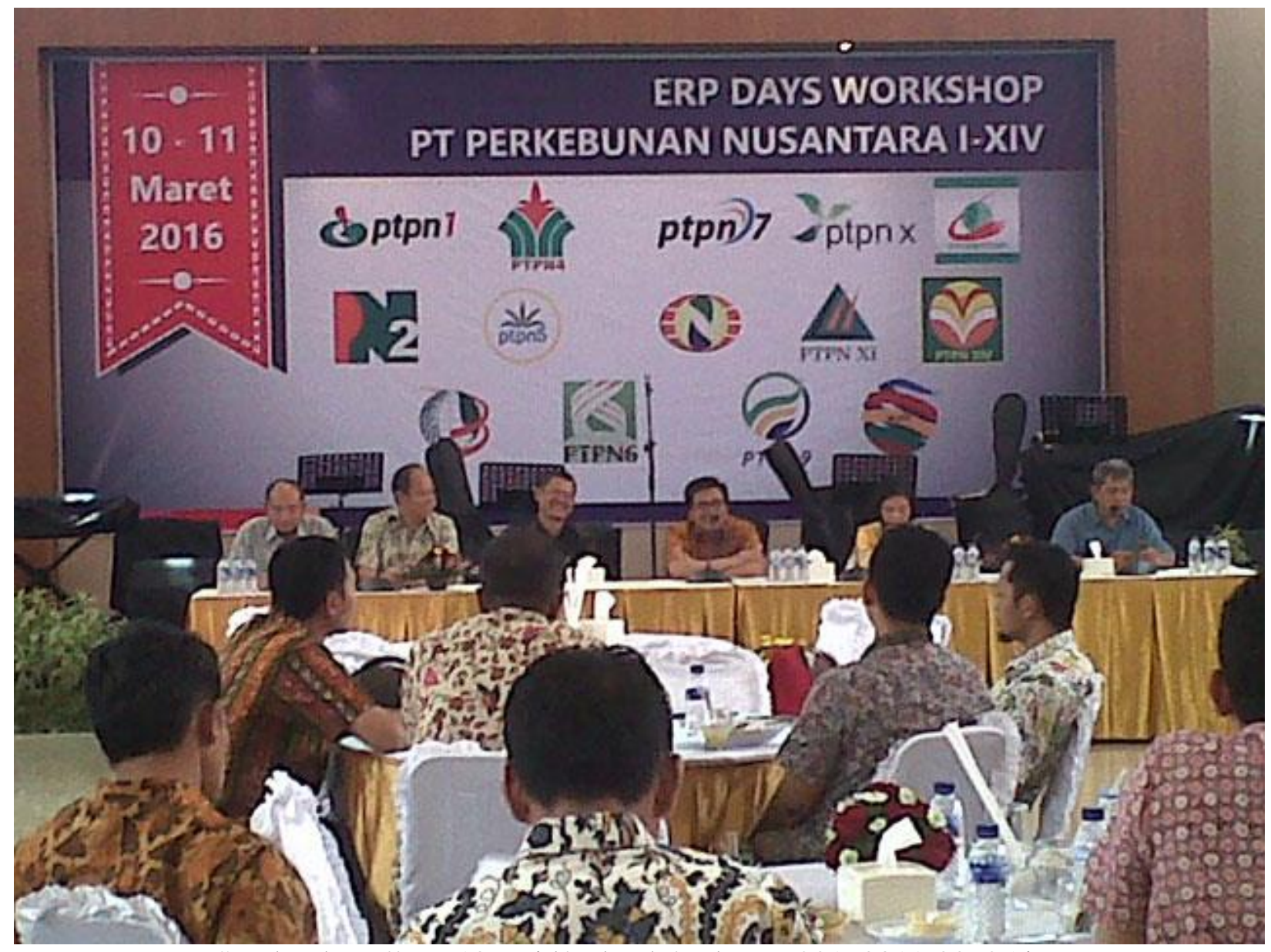

Sumber http://ptpn10.co.id/uploads/Bubutan-20160311-00985.jpg

Program Penerapan sistem teknologi informasi berbasis SAP ERP (System Applications Products - Enterprise Resource Planning) Untuk itu, PT Perkebunan Nusantara X. Kegiatan ini menerapkan SAP ERP yang kini dijadikan contoh bagi PTPN I hingga PTPN XIV. Kegiatan diinisiasi oleh Direktur Sumber Daya Manusia (SDM) dan Umum PTPN X 